\title{
Corrigendum: Watching More Closely: Shot Scale Affects Film Viewers' Theory of Mind Tendency But Not Ability
}

\author{
Brendan Rooney ${ }^{1 *}$ and Katalin E. Bálint ${ }^{2,3}$ \\ ${ }^{1}$ School of Psychology, University College Dublin, Dublin, Ireland, ${ }^{2}$ Tilburg Center for Cognition and Communication, Tilburg \\ University, Tilburg, Netherlands, ${ }^{3}$ Institute for Media, Knowledge and Communication, University of Augsburg, Augsburg, \\ Germany
}

Keywords: theory of mind, shot scale, close up shot, facial expression, characters, film

\section{OPEN ACCESS}

\section{Edited and reviewed by:} Justin H. G. Williams,

University of Aberdeen, United Kingdom

*Correspondence: Brendan Rooney brendan.rooney@ucd.ie

Specialty section: This article was submitted to Emotion Science, a section of the journal Frontiers in Psychology

Received: 04 February 2018 Accepted: 16 February 2018 Published: 01 March 2018

Citation: Rooney B and Bálint KE (2018) Corrigendum: Watching More Closely: Shot Scale Affects Film Viewers

Theory of Mind Tendency But Not Ability. Front. Psychol. 9:261. doi: 10.3389/fpsyg.2018.00261

\section{A corrigendum on}

Watching More Closely: Shot Scale Affects Film Viewers' Theory of Mind Tendency But Not Ability

by Rooney, B., and Bálint, K. E. (2018). Front. Psychol. 8:2349. doi:10.3389/fpsyg.2017.02349

In the original article, we referred to Canini et al., 2013. This was an error. It should be Canini et al., 2011. In the reference section the reference was incorrectly written as:

Canini, L., Benini, S., and Leonardi, R. (2013). Classifying cinematographic shot types. Multimed. Tools Appl. 62, 51-73. doi: 10.1007/s11042-011-0916-9

The correct reference should be:

Canini, L., Benini, S., and Leonardi, R. (2011). "Affective analysis on patterns of shot types in movies," in Proceedings of the 7th International Symposium on Image and Signal Processing and Analysis (ISPA 2011).

The authors apologize for this error and state that this does not change the scientific conclusions of the article in any way.

The original article has been updated.

Conflict of Interest Statement: The authors declare that the research was conducted in the absence of any commercial or financial relationships that could be construed as a potential conflict of interest.

Copyright $\odot 2018$ Rooney and Bálint. This is an open-access article distributed under the terms of the Creative Commons Attribution License (CC BY). The use, distribution or reproduction in other forums is permitted, provided the original author(s) and the copyright owner are credited and that the original publication in this journal is cited, in accordance with accepted academic practice. No use, distribution or reproduction is permitted which does not comply with these terms. 